\title{
EVALUATION OF AVIAN ADENOVIRUS INACTIVATION METHODS USED IN THE PRODUCTION OF INFLUENZA VACCINES
}

Savina NN ${ }^{1}$, Ekimov $A A^{1}$, Trukhin VP¹, Evtushenko AE ${ }^{1}$, Zhirenkina EN¹, Sinegubova EO ${ }^{2}$, Slita AV²

Saint Petersburg Research Institute of Vaccines and Serums, FMBA, Russia

2 Saint Petersburg Pasteur Research Institute of Epidemiology and Microbiology, Saint Petersburg, Russia

\begin{abstract}
Inactivation of influenza virus and other potential contaminants like avian adenoviruses coming from embryonated chicken eggs is a critical step in the production of inactivated influenza vaccines. Inactivation must lead to a guaranteed reduction in contaminant titers by at least 4 lg (PFU)/ml. The aim of this study was to identify an optimum cell line for adenovirus propagation and to estimate a reduction in adenovirus titers in vaccine intermediates after inactivation. In a series of experiments, we identified the optimum conditions and the optimum cell line for the propagation of avian adenovirus (strains CELO and Fontes). The most commonly used inactivation methods were analyzed, including inactivation by $\beta$-propiolactone and UV light. Viral titers were measured by plaque assays. After $10 \mathrm{~h}$ of inactivation with $\beta$-propiolactone, CELO titers fell by $4.12 \pm 0.06 \mathrm{lg}$, whereas Fontes titers, by $4.20 \pm 0.19 \mathrm{lg}$, suggesting that $\beta$-propiolactone is an effective inactivating agent. Exposure to UV light led to a reduction in CELO titers by $4.69 \pm 0.89 \mathrm{lg}$ and a reduction in Fontes titers by $4.44 \pm 1.06 \mathrm{lg}$ after 5 min. $\mathrm{N}$-octyl- $\beta$-D-glucopyranoside added at the splitting step reduced CELO titers by $0.93 \pm 0.15 \mathrm{lg}$ and Fontes titers by $1.04 \pm 0.12 \mathrm{lg}$, whereas tetradecyltrimethylammonium bromide led to a reduction in CELO and Fontes titers by $1.18 \pm 0.17 \mathrm{lg}$ and $1.12 \pm 0.38 \mathrm{lg}$, respectively.
\end{abstract}

Keywords: influenza vaccine, inactivation, avian adenovirus, propiolactone, UV radiation

Author contribution: all authors have equally contributed to the methodology of the study, analysis and interpretation of the results and manuscript preparation.

Compliance with ethical standards: the study complied with the principles of the Declaration of Helsinki (1964) and its revisions.

$\triangle$ Correspondence should be addressed: Natalya N. Savina

Svobody, 52, Krasnoye Selo, Saint Petersburg, 198320; n.n.savina@spbniivs.ru

Received: 18.08.2021 Accepted: 12.09.2021 Published online: 26.09.2021

DOI: $10.47183 /$ mes.2021.032

\section{ОЦЕНКА МЕТОДОВ ИНАКТИВИРОВАНИЯ АДЕНОВИРУСА ПТИЦ ПРИ ПРОИЗВОДСТВЕ ГРИППОЗНЫХ ВАКЦИН}

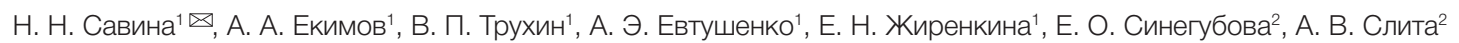

${ }^{1}$ Санкт-Петербургский научно-исследовательский институт вакцин и сывороток и предприятие по производству бактерийных препаратов Федерального медико-биологического агентства, Санкт-Петербург, Россия

${ }^{2}$ Санкт-Петербургский научно-исследовательский институт эпидемиологии и микробиологии имени Пастера, Санкт-Петербург, Россия

\begin{abstract}
При производстве инактивированных гриппозных вакцин на стадии инактивации должен быть инактивирован как вирус гриппа, так и возможные вирусные контаминанты (например, аденовирус птиц), которые могут попасть в вакцину из сырья (куриных эмбрионов). Инактиваторы должны обеспечивать гарантированное снижение вирусной нагрузки контаминанта не менее чем на $4 \mathrm{lg}$ (БОЕ)/мл, что обеспечит его отсутствие в готовой вакцине. Целью работы было выбрать клеточную линию для наработки аденовируса и оценить снижение титра аденовируса в полупродуктах гриппозных вакцин при воздействии инактиваторов. Были подобраны оптимальные условия наработки аденовируса птиц штаммов CELO и Fontes в культуре клеток, в качестве оптимальной выбрана культура клеток Vero; рассмотрены основные используемые инактиваторы: $\beta$-пропиолактон и УФ-излучение. Титры аденовируса определяли методом бляшкообразования. Спустя 10 ч инактивации $\beta$-пропиолактоном аденовирус штамма CELO показал сHижение вирусной нагрузки на 4,12 \pm 0,06 lg, а аденовирус штамма Fontes - на 4,20 \pm 0,19 lg, что указывает на эффективное действие $\beta$-пропиолактона при инактивации. Проведение инактивации УФ-излучением позволяет снизить вирусную нагрузку штамма CELO на 4,69 \pm 0,89 lg, a штамма Fontes - на 4,44 $\pm 1,06$ lg за 5 мин. Отмечено, что добавление детергента на стадии расщепления также снижает вирусную нагрузку на 0,93 $\pm 0,15$ lg и 1,04 $\pm 0,12$ lg для штаммов CELO и Fontes соответственно при использовании н-октил- $\beta$-D-глюкопиранозида и на 1,18 \pm 0,17 lg и 1,12 \pm 0,38 lg при использовании тетрадецилтриметиламмоний бромида.
\end{abstract}

Ключевые слова: гриппозные вакцины, инактивация, аденовирус птиц, пропиолактон, УФ-излучение

Вклад авторов: все авторы внесли равнозначный вклад в разработку методики исследования, получение, анализ и интерпретацию данных, в написание и редактирование статьи.

Соблюдение этических стандартов: исследование проведено с соблюдением этических принципов Хельсинкской декларации Всемирной медицинской ассоциации 1964 г. и последующих ее пересмотров.

$\triangle$ Для корреспонденции: Наталья Николаевна Савина

ул. Свободы, д. 52, г. Красное Село, г. Санкт-Петербург, 198320; n.n.savina@spbniivs.ru

Статья получена: 18.08.2021 Статья принята к печати: 12.09.2021 Опубликована онлайн: 26.09.2021

DOI: $10.47183 /$ mes.2021.032

One of the key steps in the production of inactivated influenza vaccines is influenza virus inactivation for the safety of the final product. The World Health Organization and the European Medicines Agency [1, 2] require that influenza virus should be completely inactivated during this step. It is known that vaccine intermediates can potentially contain other contaminants like avian leukosis virus, avian adenoviruses and mycoplasmas. So, the guidelines prescribe that the inactivation step should be effective against these pathogens, too.
Technologically, inactivation can be achieved by physical or chemical methods. The most widespread physical method is irradiation with ultraviolet light; one of the commonly used chemical methods is exposure to alkylating agents, such as $\beta$-propiolactone [3].

Avian adenoviruses cause a chronic infection in birds and are lethal for chicken embryos (CE). Avian adenoviruses are members of the Aviadenovirus genus. So far, 12 serologically distinct types of avian adenoviruses from CELO (Chicken 
Embryo Lethal Orphan) and GAL (Gallus Adeno-Like) virus groups are recognized; one more serotype is represented by the causative agent of the egg drop syndrome (EDS-76) [4].

In chickens, adenovirus infection manifests as inclusion body hepatitis, hepatitis-hydropericardium syndrome, gizzard erosion, respiratory conditions, growth retardation, and joint inflammation [5].

Avian adenovirus infection often develops as a secondary infection in poultry with infectious bronchitis, mycoplasma infection and other respiratory diseases.

Now and then, outbreaks of avian adenovirus infection occur on poultry farms across Russia [6, 7].

According to the literature, adenoviruses can be inactivated with formaldehyde [8]; however, the efficacy of this method has been tested on influenza virus and adenoviruses propagated in MDCK cells; therefore, the results cannot be extrapolated to the egg-based technology of influenza vaccine production. It is known that formaldehyde reduces the immunogenicity of the final vaccine to a much greater extent than $\beta$-propiolactone; besides, $\beta$-propiolactone inactivates influenza more effectively [9].

As an inactivating agent, $\beta$-propiolactone is preferred over formaldehyde because $\beta$-propiolactone hydrolyzes to 3-hydroxypropionic acid, an intermediate product of lipid metabolism in humans [10]; this has a beneficial effect on vaccine safety.

The aim of this study was to find an optimum virucidal agent for the inactivation of influenza vaccine contaminants (CELO and GAL viruses) and to determine the minimum inactivation time needed for a guaranteed reduction in viral titers by at least $4 \mathrm{lg}(\mathrm{PFU}) / \mathrm{ml}[11]$

\section{METHODS}

\section{Material}

The avian adenovirus from the Adenoviridae family, Aviadenovirus, Fowl adenovirus A, Fowl adenovirus 1, strain: Phelps (CELO), ATCC VR-432 (ATCC collection; USA).

The avian adenovirus from the Adenoviridae family, Aviadenovirus, Fowl adenovirus D, Fowl adenovirus 2, strain: Fontes, ATCC VR-280 (ATCC collection; USA).

HEp-2 cells (collection of cell cultures of Saint Petersburg Pasteur Research Institute of Epidemiology and Microbiology; Russia).

MA-104 cells (collection of cell cultures of Saint Petersburg Pasteur Research Institute of Epidemiology and Microbiology; Russia).

Vero cells (collection of cell cultures of Saint Petersburg Pasteur Research Institute of Epidemiology and Microbiology; Russia).

\section{Cultivation of CELO and Fontes viruses and measurement of infectious titers}

The optimum cell culture for the propagation of adenoviruses was selected from 3 candidate cell lines: Vero B, MA-104 and HEp-2. The cells were cultured in the alpha-MEM growth medium supplemented with Gibco's heat-inactivated fetal bovine serum (10\%), 2 mM L-glutamine and $100 \mu \mathrm{g} / \mathrm{ml}$ gentamicin. The maintenance medium used in the experiment contained 2\% FBS, as opposed to 10\% FBS in the growth medium. The cells were seeded at 500,000 cells/ml and grown overnight in culture flasks (surface area: $25 \mathrm{~cm} 2$ ) at $37^{\circ} \mathrm{C}$ and $5 \% \mathrm{CO}_{2}$ until a monolayer was formed.

The cell cultures were infected with Phelps or Fontes strains and grown at $37^{\circ} \mathrm{C}$ and $5 \% \mathrm{CO}_{2}$ until $80-90 \%$ of the monolayer was destroyed. The flasks were frozen at $-20^{\circ} \mathrm{C}$; after thawing, adenovirus titers were determined as described below.

The cells were plated in 24-well plates at 500,000 cells $/ \mathrm{ml}$ and cultured overnight at $37{ }^{\circ} \mathrm{C}$ and $5 \% \mathrm{CO}_{2}$ until a monolayer was formed. Then, the cells were infected with serial tenfold dilutions (from $10^{-1}$ to $10^{-7}$ ) of the viral stocks and incubated for 30 min at room temperature. After that, the cells were washed in culture medium; MEM was mixed with Avicel (SigmaAldrich; USA) at a $1: 1$ ratio and added to the washed cells. Then, the cells were incubated for $96 \mathrm{~h}$ at $37{ }^{\circ} \mathrm{C}$ and $5 \% \mathrm{CO}_{2}$. After that, the cells were stained with $1 \mathrm{ml}$ of $0.1 \%$ alcohol crystal violet for 15 min, washed with distilled water, dried at room temperature, and viral plaques were counted in each well. Based on the obtained counts, viral titers were determined using a method proposed by Reed and Muench [12]; the titers were expressed as PFU/ml.

\section{Virus-containing allantoic fluid}

Influenza virus was cultured in 9-11-day old embryonated chicken eggs. The embryos were challenged with 102,0-104,5 $E D_{50} / 0.2 \mathrm{ml}$. The eggs inoculated with type A influenza virus were incubated at $35^{\circ} \mathrm{C}$ for $48 \mathrm{~h}$; those infected with type $\mathrm{B}$ influenza virus were incubated for $72 \mathrm{~h}$. After incubation, the eggs were cooled and the virus-containing allantoic fluid (AF) was harvested.

\section{Viral concentrates (VC)}

AF was filtered through a cascade of 10,6 and $1 \mu \mathrm{m}$ filters and run through a $300 \mathrm{kDa}$ ultrafiltration unit. The obtained concentrate was centrifuged in a sucrose density gradient (60-20\%). Then, 40-25\% gradient fractions were collected.

\section{Statistical analysis}

Statistical analysis was conducted in Microsoft Excel 365 (Microsoft corp.; USA) and Minitab 19 (Minitab Inc.; USA) and involved calculation of 95\% confidence intervals.

\section{RESULTS}

\section{Optimum cell line for avian adenovirus production}

Three candidate cell lines were tested: Vero, MA-104 and HEp-2. These are the most commonly used cell lines for the propagation of adenoviruses. The infectious titers of CELO and Fontes viruses cultured in these cell lines are provided in Table 1.

Both adenoviruses propagated in Vero cells more effectively than in MA-104 and HEp-2: their titers in Vero cells were by at

Table 1. Infectious titers of CELO and Fontes adenoviruses cultured in different cell lines

\begin{tabular}{|c|c|c|c|}
\hline & \multicolumn{3}{|c|}{ Infectious titers, PFU/ml } \\
\hline Virus & Vero & HEp-2 & MA-104 \\
\hline CELO & $4.3 \pm 2.3 \times 10^{6}$ & $6.5 \pm 3.0 \times 10^{3}$ & $1.1 \pm 0.2 \times 10^{3}$ \\
\hline Fontes & $3.3 \pm 1.5 \times 10^{6}$ & $9.7 \pm 3.8 \times 10^{3}$ & $2.0 \pm 0.7 \times 10^{3}$ \\
\hline
\end{tabular}




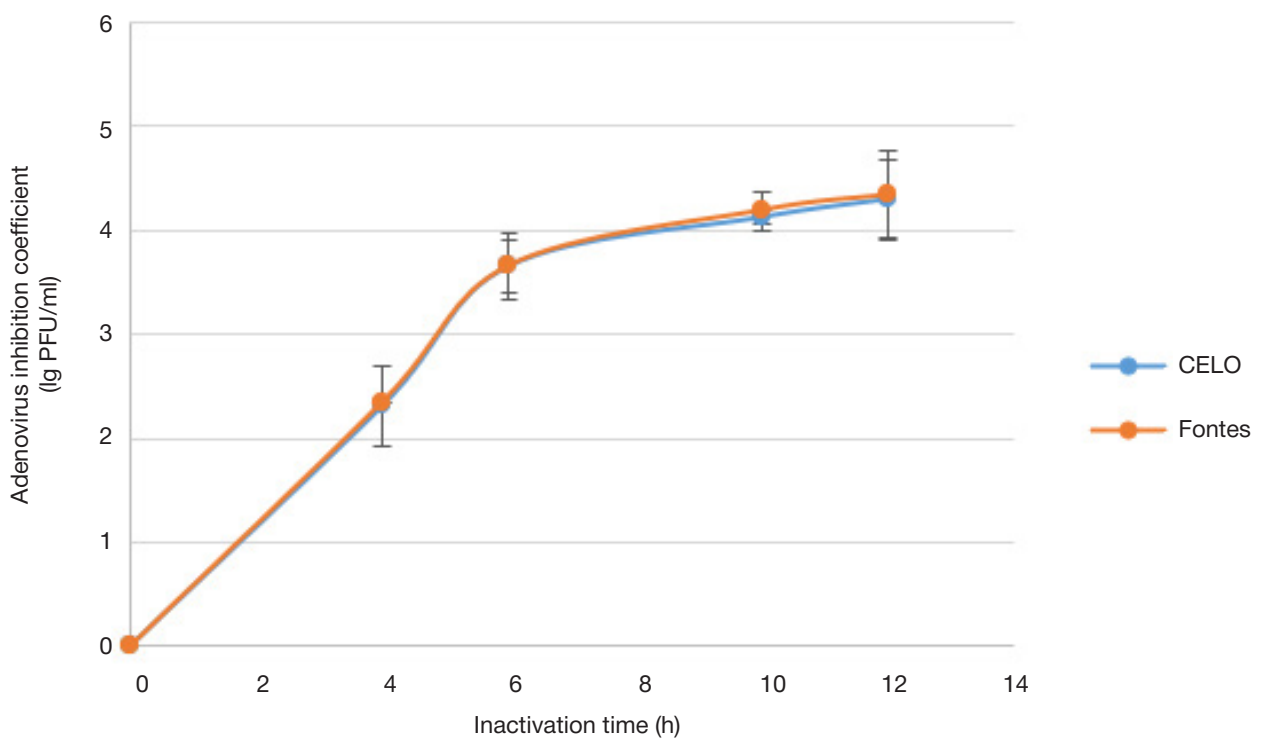

Fig. 1. Dynamics of CELO and Fontes inactivation in the presence of $\beta$-propiolactone

least 2 lg higher. In other words, Vero cells turned out to be the most permissive cells for both studied avian adenoviruses.

\section{Dynamics of avian adenovirus inactivation in allantoic fluid by $\beta$-propiolactone}

To model inactivation of avian adenoviruses in allantoic fluid by $\beta$-propiolactone, the titrated viral stock (10\% of the AF volume) was added to AF so that the final viral titer was at least 105 $\mathrm{PFU} / \mathrm{ml}$. The mixture was inactivated with $\beta$-propiolactone $(0.09 \%$ in the final mixture) and viral titers were measured in the samples. Inactivation dynamics are shown in Fig. 1.

A reduction in viral titers by at least $4 \mathrm{lg} P F U / \mathrm{ml}$ occurred no sooner than $10 \mathrm{~h}$ after adding $\beta$-propiolactone; in other words, allantoic fluid used in the production of influenza vaccines should be exposed to $\beta$-propiolactone for inactivation for at least $10 \mathrm{~h}$.

\section{Dynamics of avian adenovirus inactivation in virus concentrates by exposure to UV light}

To model inactivation of avian adenoviruses in VC by irradiation with UV light, the titrated viral stock (10\% of the VC volume) was added to VC so that the final viral titer was at least $10^{5}$
PFU/ml. Contaminated VC was placed in $90 \mathrm{~mm}$ Petri dishes. The dishes were exposed to 4 UV lamps (total power: $60 \mathrm{~W}$ ) installed at a $20 \mathrm{~cm}$ distance from the dishes. The following UV irradiation protocol was applied:

Dish 1 - $0 \mathrm{~s}$;

Dish $2-30 \mathrm{~s}$;

Dish $3-1 \mathrm{~min}$;

Dish $4-2$ min;

Dish $5-5$ min.

After time points specified in the protocol, $1 \mathrm{ml}$ samples of VC were collected from the dishes to quantify the number of plaques and thus determine the viral titer. Inactivation dynamics are shown in Fig. 2

A reduction in viral titers by at least $4 \mathrm{lg} P F U / \mathrm{ml}$ occurred no sooner than after 5 min of exposure; in other words, exposure to UV light for the inactivation of viral particles in allantoic fluid during the production of influenza vaccines should last at least $5 \mathrm{~min}$.

\section{Dynamics of avian adenovirus inactivation in virus concentrates by detergents}

To model inactivation of avian adenoviruses in VC by exposure to detergents, the titrated viral stock ( $10 \%$ of the VC volume)

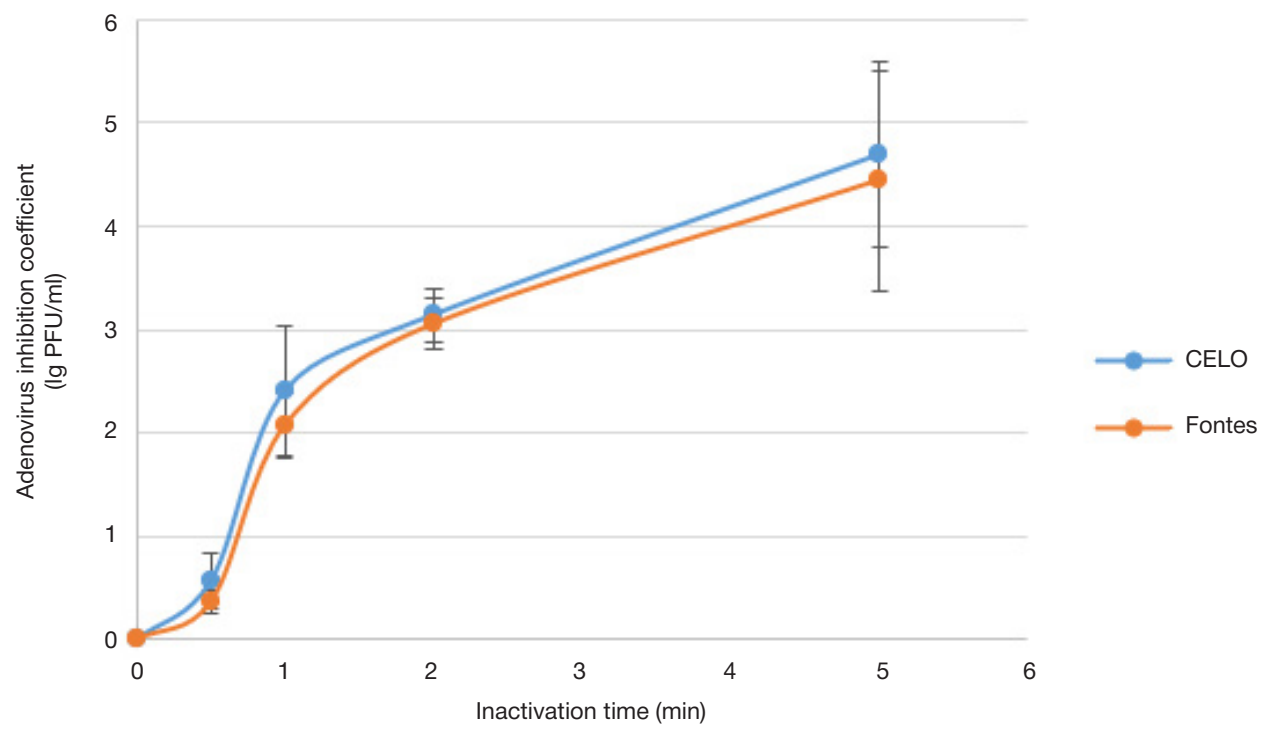

Fig. 2. Dynamics of CELO and Fontes inactivation by UV light 


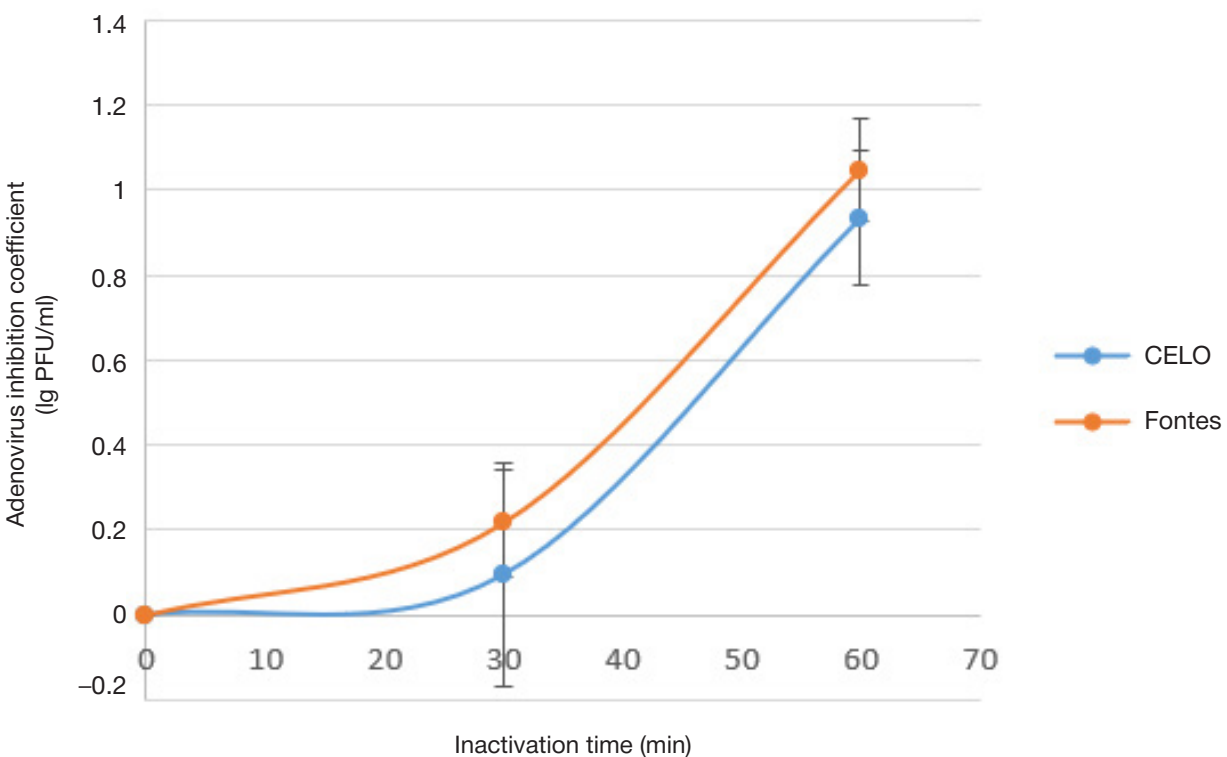

Fig. 3. Dynamics of CELO and Fontes inactivation by n-octyl- $\beta$-D-glucopyranoside was added to VC so that the final viral titer was at least $10^{5}$ $\mathrm{PFU} / \mathrm{ml}$. Then, contaminated VC samples were combined with the solutions of $n$-octyl- $\beta$-D-glucopyranoside (total protein to detergent ratio: $1: 8$ ) or tetradecyltrimethylammonium bromide (total protein to detergent ratio: $1: 0.5$ ) in PBS, and viral titers were determined. Inactivation dynamics are shown in Fig. 3 and 4.

A reduction in viral titers by at least $1 \mathrm{lg}$ PFU/ml occurred after $1 \mathrm{~h}$ of exposure to the detergents. Following exposure to n-octyl$\beta$-D-glucopyranoside, CELO titers fell by $0.93 \pm 0.15 \mathrm{lg}$ and Fontes titers fell by $1.04 \pm 0.12 \mathrm{lg}$. With tetradecyltrimethylammonium bromide, CELO titers fell by $1.18 \pm 0.17 \mathrm{lg}$ and Fontes titers fell by $1.12 \pm 0.38 \mathrm{lg}$.

\section{DISCUSSION}

Inactivation by $\beta$-propiolactone and by exposure to UV light is effective against the avian adenovirus strains Fontes and CELO. However, the variability of the results is greater for UV irradiation (Table 2).

These findings may indicate that the UV-based inactivation method is less reliable and may increase the risk of producing a

poor-quality influenza vaccine. Most pharmaceutical companies in Russia and abroad employ chemical methods of inactivation. For example, Novartis, ID Biomedical Corp of Quebec and Saint Petersburg Research Institute of Vaccines and Serums (FMBA, Russia) use $\beta$-propiolactone as an inactivating agent in the production of influenza vaccines [13-15]. Apart from influenza virus, $\beta$-propiolactone can inactivate avian adenoviruses, which are potential contaminants of influenza vaccine intermediates.

\section{CONCLUSIONS}

We have selected the optimum cell line for the propagation of Fontes and CELO adenoviruses: Vero cells allow more effective propagation ( $\sim$ by $2 \mathrm{lg}$ ) of these adenovirus strains than Hep2 and MA-104 cells. Virus-containing allantoic fluid used in the production of influenza vaccines should be exposed to $\beta$-propiolactone for inactivation for at least $10 \mathrm{~h}$ to ensure a reduction in avian adenovirus titers by $4 \mathrm{lg} \mathrm{PFU} / \mathrm{ml}$. If inactivation is performed with UV light, exposure should last at least 5 min to reduce viral titers by $4 \mathrm{lg} \mathrm{PFU} / \mathrm{ml}$. In the production of split influenza vaccines, an additional reduction in viral titers by $1 \mathrm{lg} \mathrm{PFU} / \mathrm{ml}$ can be achieved by using detergents.

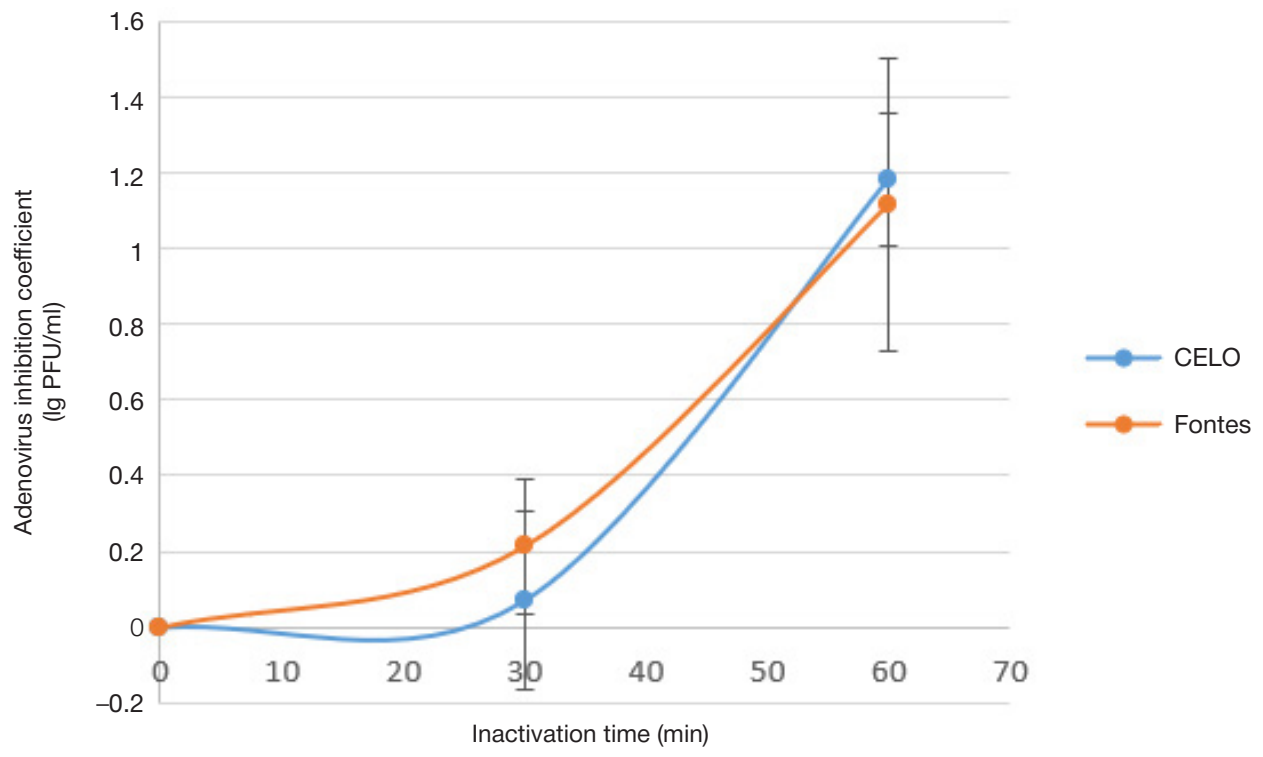

Fig. 4. Dynamics of CELO and Fontes inactivation by tetradecyltrimethylammonium bromide 
Table 2. A reduction in adenovirus titers following exposure to different inactivating agents

\begin{tabular}{|c|c|c|}
\hline \multirow{2}{*}{ Inactivating agent } & \multicolumn{2}{|c|}{ Strain } \\
\cline { 2 - 3 } & CELO & Fontes \\
\hline $\begin{array}{c}\beta \text {-propiolactone } \\
\text { (inactivation time: } 10 \mathrm{~h} \text { ) }\end{array}$ & $4.12 \pm 0,06 \mathrm{lg} \pm 0.19 \mathrm{lg}$ \\
\hline $\begin{array}{c}\text { UV light } \\
\text { (inactivation time: } 5 \mathrm{~min} \text { ) }\end{array}$ & $4.69 \pm 0,89 \mathrm{lg}$ & $4.44 \pm 1.06$ \\
\hline
\end{tabular}

So, the technology of influenza vaccine production that involves inactivation of allantoic fluid by $\beta$-propiolactone for $10 \mathrm{~h}$ followed by inactivation with detergents for $1 \mathrm{~h}$ guarantees complete inactivation of avian adenoviruses in the vaccine. However, avian adenoviruses are not the only vaccincontaminants, and further research is needed to study the kinetics of $\beta$-propiolactone-based inactivation of avian leukosis virus and mycoplasmas.

\section{References}

1. Guideline on Influenza vaccines - Quality module. EMA/CHMP/ BWP/310834/2012 Rev.1 Committee for Medicinal Products for Human use (CHMP), 2017. Available from: https://www.ema. europa.eu/en/documents/scientific-guideline/guideline-influenzavaccines-quality-module-revision-1 en.pdf.

2. Serija tehnicheskih dokladov VOZ, \# 927, 2005 god. Prilozhenie 3. Rekomendacii po proizvodstvu i kontrolju vakcin protiv grippa (inaktivirovannyh). Russian.

3. Sabbaghi A, Miri SM, Keshavarz M, Zargar M, Ghaemi A. Inactivation methods for whole influenza vaccine production. Rev Med Virol. 2019 Nov; 29 (6): e2074.

4. King AMQ, Adams MJ, Carstens EB, Leftkowitc EJ, editors. Virus Taxonomy: Classification and Nomenclature of Viruses. Ninth Report of the International Committee on Taxonomy of Viruses. Elsevier, 2012; 1327 p.

5. Qing Pan, Jing Wang, Yulong Gao, Qi Wang, Hongyu Cui, Changjun Liu, et al. Identification of chicken CAR homology as a cellular receptor for the emerging highly pathogenic fowl adenovirus 4 via unique binding mechanism, Emerging Microbes \& Infections. 2020; 9 (1): 586-96.

6. Bakulin V. A., Muryj V. A. Adenovirusnyj gepatit s vkljuchenijamigidroperikardit kur: jepizootologija, diagnostika i specificheskaja profilaktika. Bio. 2011; 12: 28-30. Russian.

7. Borisov VV. Razrabotka sredstv i metodov diagnostiki specificheskoj profilaktiki adenovirusnyh boleznej kur [dissertacija]. Ivanovo, 2007.

8. Kap M, Arron Gl, Loibner M, Hausleitner A, Siaulyte G, Zatloukal K, Riegman P. Inactivation of Influenza A virus, Adenovirus, and Cytomegalovirus with PAXgene Tissue Fixative and Formalin. Biopreservation and Biobanking. 2013; 11 (4): 229-34.

\section{Литература}

1. Guideline on Influenza vaccines - Quality module. EMA/CHMP/ BWP/310834/2012 Rev.1 Committee for Medicinal Products for Human use (CHMP), 2017. Available from: https://www.ema. europa.eu/en/documents/scientific-guideline/guideline-influenzavaccines-quality-module-revision-1_en.pdf.

2. Серия технических докладов ВОЗ, № 927, 2005 год. Приложение 3. Рекомендации по производству и контролю вакцин против гриппа (инактивированных).

3. Sabbaghi A, Miri SM, Keshavarz M, Zargar M, Ghaemi A. Inactivation methods for whole influenza vaccine production. Rev Med Virol. 2019 Nov; 29 (6): e2074.

4. King $A M Q$, Adams MJ, Carstens EB, Leftkowitc EJ, editors. Virus Taxonomy: Classification and Nomenclature of Viruses. Ninth Report of the International Committee on Taxonomy of Viruses. Elsevier, 2012; 1327 p.

5. Qing Pan, Jing Wang, Yulong Gao, Qi Wang, Hongyu Cui, Changjun Liu, et al. Identification of chicken CAR homology as a cellular receptor for the emerging highly pathogenic fowl
9. Herrera-Rodriguez J, Signorazzi A, Holtrop M, de Vries-Idema J, Huckriede A. Inactivated or damaged? Comparing the effect of inactivation methods on influenza virions to optimize vaccine production. Vaccine. 2019; 37 (12): 1630-7.

10. Shuo Lei, Xun Gao, Yang Sun, Xiangyong Yu, Longshan Zhao. Gas chromatography-mass spectrometry method for determination of $\beta$-propiolactone in human inactivated rabies vaccine and its hydrolysis analysis, Journal of Pharmaceutical Analysis. 2018; 8 (6): 373-7.

11. Rukovodstvo po issledovaniju validacii virusnoj ochistki: proektirovanie, vklad i interpretacija issledovanij, ispol'zujushhih inaktivaciju i udalenie virusov. EMA CPMP/BWP/268/95; 1996. Russian.

12. Reed LJ, Muench $\mathrm{H}$. A simple method of estimating fifty percent endpoints. The American Journal of Hygiene. 1938; 27: 493-7.

13. Haussmann $C$, Hauschild F, Jobst B, Novartis AG, assignee. Improvements in preparation of influenza virus vaccine antigens. United States patent US № US6986808P. 18.03.2008.

14. Burt DS, Jones DH, Lowell GH, White GL, Torossian K, Fries LF, assignee. ID Biomedical Corp of Quebec. Proteosome influenza vaccine. United States patent US № US18247600P. 15.02.2000.

15. Truhin VP, Evtushenko AYe, Krasilnikov IV, Savina NN, Bykov DG, Ujba SV, Vasilev AN, Ryskova EV, Nacharova EP, Arakelov SA, avtory; Federal'noe gosudarstvennoe unitarnoe predprijatie «Sankt-Peterburgskij nauchno-issledovatel'skij institut vakcin i syvorotok i predprijatie po proizvodstvu bakterijnyh preparatov» Federal'nogo mediko-biologicheskogo agentstva (FGUP SPbNIIVS FMBA Rossii), patentoobladatel'. Sposob poluchenija antigena ili antigenov dlja proizvodstva protivogrippoznoj vakciny i vakcina na ego osnove. Patent RF \# RU2019118695A. 14.06.2019. Russian.

adenovirus 4 via unique binding mechanism, Emerging Microbes \& Infections. 2020; 9 (1): 586-96.

6. Бакулин В. А., Мурый В. А. Аденовирусный гепатит с включениями-гидроперикардит кур: эпизоотология, диагностика и специфическая профилактика. Био. 2011; 12: 28-30.

7. Борисов В. В. Разработка средств и методов диагностики и специфической профилактики аденовирусных болезней кур [диссертация]. Иваново, 2007.

8. Kap M, Arron Gl, Loibner M, Hausleitner A, Siaulyte G, Zatloukal K, Riegman P. Inactivation of Influenza A virus, Adenovirus, and Cytomegalovirus with PAXgene Tissue Fixative and Formalin. Biopreservation and Biobanking. 2013; 11 (4): 229-34.

9. Herrera-Rodriguez J, Signorazzi A, Holtrop M, de Vries-Idema J, Huckriede A. Inactivated or damaged? Comparing the effect of inactivation methods on influenza virions to optimize vaccine production. Vaccine. 2019; 37 (12): 1630-7.

10. Shuo Lei, Xun Gao, Yang Sun, Xiangyong Yu, Longshan Zhao. Gas chromatography-mass spectrometry method for determination 
of $\beta$-propiolactone in human inactivated rabies vaccine and its hydrolysis analysis, Journal of Pharmaceutical Analysis. 2018; 8 (6): 373-7.

11. Руководство по исследованию валидации вирусной очистки: проектирование, вклад и интерпретация исследований, использующих инактивацию и удаление вирусов. ЕМА СРМР/ BWP/268/95; 1996.

12. Reed LJ, Muench $H$. A simple method of estimating fifty percent endpoints. The American Journal of Hygiene. 1938; 27: 493-7.

13. Haussmann $C$, Hauschild F, Jobst B, Novartis AG, assignee. Improvements in preparation of influenza virus vaccine antigens. United States patent US № US6986808P. 18.03.2008.

14. Burt DS, Jones DH, Lowell GH, White GL, Torossian K, Fries LF, assignee. ID Biomedical Corp of Quebec. Proteosome influenza vaccine. United States patent US № US18247600P. 15.02.2000. 15. Трухин В. П., Евтушенко А. Э., Красильников И. В., Савина Н. Н., Быков Д. Г., Уйба С. В., Васильев А. Н., Рыськова Е. В., Начарова Е. П., Аракелов С. А., авторы; Федеральное государственное унитарное предприятие "СанктПетербургский научно-исследовательский институт вакцин и сывороток и предприятие по производству бактерийных препаратов» Федерального медико-биологического агентства (ФГУП СПбНИИВС ФМБА России), патентообладатель. Способ получения антигена или антигенов для производства противогриппозной вакцины и вакцина на его основе. Патент PФ № RU2019118695A. 14.06.2019. 